\title{
The Effect of Phytophagous Nematode Graz- ing on Blue Grama Die-off
}

NANCY L. STANTON, DENNIS MORRISON, AND WILLIAM A. LAYCOCK

\section{Abstract}

Nematode populations were sampled in ungrazed and heavily grazed areas in northeastern Colorado under patches of healthy, senescing, and dead blue grama to test the hypothesis that phytophagous nematodes may cause the senescence. Densities of plant parasites were significantly different under the 3 plant types. Live blue grama supported the highest numbers $\left(1.2 \times 10 \% / \mathrm{m}^{2}\right)$ and dead blue grama, the lowest $\left(2 \times 10^{5} / \mathrm{m}^{2}\right)$. Bacterial feeding nematodes also varied significantly with plant type. Highest densities were found under senescing plants $\left(2.4 \times 10^{6} / \mathrm{m}^{2}\right)$ and lowest densities were under dead plants $\left(7 \times 10^{5} / \mathrm{m}^{2}\right)$. Total densities were slightly but insignificantly lower in the heavily grazed area. Scarlet globemallow and fringed sagewort supported lower populations of both plant parasites and bacterial feeders than did live blue grama. The densities under live blue grama were not unusually high and well within the values reported in the literature for arid grasslands. Thus, nematode root grazing may decrease net primary production but we conclude that nematodes themselves were not the major cause of the die-off.

Blue grama (Bouteloua gracilis (H.B.K.) Griffiths is the dominant plant species on the shortgrass plains in eastern Colorado. In the early to mid 1970's large patches of senescing and dead blue grama plants were observed. By 1977 the Central Plains Experimental Range, the Pawnee National Grasslands, and other shortgrass areas in northeastern Colorado had large areas of dead and dying blue grama (Weiner and Capinera 1980). Initially, nothing was known about the cause of the die-off. However, large numbers of white grubs, the larvae of a May beetle (Phyllophaga fimbripes LeConte), were found in the dic-off areas. White grubs are root feeders which were suspected to be the cause of the blue grama die-off (Weiner and Capinera 1980). The present study of nematode populations was one of the several investigations to study other possible causes of the damage to blue grama.

Nematodes are a major faunal component in grassland soils and some studies have suggested that they are one of the major herbivores (Scott et al. 1979). In short-grass and mixed-grass prairies, nematodes may significantly reduce both shoot (Smolik 1974, 1977) and root production (Stanton et al. 1981, Stanton 1983) anywhere from 13 to $60 \%$. If further work confirms these results, plant parasitic nematodes will be established as a major factor affecting primary production and vitality of native grasslands. Therefore, in 1978, in conjunction with the study of white grubs, we sampled patches of blue grama in various states of health to determine if root grazing by phytophagous nematodes might be contributing to the die-off.

\footnotetext{
Authors are with the Department of Zoology and Physiology, University of Wyoming, Laramie 82071; and with the USDA, Agricultural Research Service (Forage, Range, and Livestock Management Research). Colorado State University. Fort Collins 80523 .

This work was supported by USDA, Agricultural Research Service, Fort Collins, Colo.

The authors express their thanks to A.M. Wilson, W. Krueger, and J.K. Lewis for reviewing the manuscript.

Manuscript accepted January 9, 1984
}

\section{Methods}

\section{Study Site}

The study was conducted on the Central Plains Experimental Range (CPER) operated by the USDA Service, Agricultural Research, $18 \mathrm{~km}$ NE of Nunn, Colo. The vegetation is shortgrass prairie dominated by blue grama with other grasses, sedges, forbs, and pricklypear cactus (Opuntia polyacantha Haw.) also present. The mean annual precipitation at CPER is $31 \mathrm{~cm}$, based on 30 years of data. May through August are the wettest months, accounting for more than $50 \%$ of the annual precipitation. Monthly mean temperatures vary from a high of $22^{\circ} \mathrm{C}$ in July to a low of $-2^{\circ} \mathrm{C}$ in January.

\section{Sampling Areas}

Two areas were selected for sampling. One was in the Environmental Stress Plot (ESA) initially established by the Grassland IBP. The site we selected was adjacent to areas previously manipulated but it had not received any treatment other than relief from ungulate grazing pressure. The other site had been heavily grazed by cattle during summers since 1939 . In both areas, soil is an Ascalon sandy clay loam and blue grama was the dominant species.

Both areas could be characterized by numerous patches of senescing and dead blue grama. The most prevalent pattern was apparently healthy blue grama surrounded by senescing plants that could be identified by the mixture of dead and live leaves. In the center of these patches were dead blue grama plants. Most dead plants were widely spaced. Thus it appeared that the die-off began in the center and moved outward in all directions.

A large representative patch in each area was selected for sampling and was divided into 4 quarter circle quadrants. Two cores, randomly selected, were taken from each quadrant within each of the 3 plant types for a total of 8 replicates taken each time of sampling. Cores were $4.8 \mathrm{~cm}$ in diameter and $10 \mathrm{~cm}$ deep. In 1978 the ungrazed plot was sampled on June 5, June 27, and August 4, and the grazed plot was sampled on June 27 and August 4.

Vegetation was not sampled on the plots where the soil samples were taken; but adjacent dead patches, senescing areas, and healthy areas were sampled on $.09 \mathrm{~m}^{2}$ quadrats. Weight of individual species was estimated and converted to oven-dry weights based on clipped samples.

The dead patches were dominated by annual forbs in both areas (Table 1). Pricklypear cactus and scarlet globemallow (Sphaeralcea coccinea (Pursh) Rydb.) were the main perennial species occurring in the dead patches in both areas. Fringed sagewort (Artemisia frigida Wild.) was also abundant within the dead patches in the ungrazed area. Additional cores for nematode extraction (8 replicates in each area) were taken within the quadrants of the dead patches only to include the roots of scarlet globemallow in the grazed area and the roots of fringed sagewort in the ungrazed area.

Each soil core was returned to the laboratory, suspended in cold water, and the suspension sieved (No. 325 sieve) to remove nema- 
Table 1. Peak aboveground standing crop ( $\mathrm{Kg} / \mathrm{ha}$, oven dry) on dead blue grama patches and adjacent live blue grama in areas similar to those where soil samples were extracted to determine nematode densities.

\begin{tabular}{|c|c|c|c|c|}
\hline \multirow[b]{2}{*}{ Species } & \multicolumn{2}{|c|}{ Dead blue grama patches } & \multicolumn{2}{|c|}{ Adjacent live blue grama } \\
\hline & Not grazed & Heavily grazed & Not grazed & Heavily grazed \\
\hline $\begin{array}{l}\text { Bouteloua gracilis } \\
\text { Uther perennial grasses and sedges } \\
\text { Artemisia frigida } \\
\text { Sphaeralcea coccinea } \\
\text { Other perennial forbs } \\
\text { Total perennial herbaceous }\end{array}$ & $\begin{array}{r}52 \\
15 \\
141 \\
317 \\
4 \\
529\end{array}$ & $\begin{array}{r}18 \\
24 \\
0 \\
214 \\
48 \\
304\end{array}$ & $\begin{array}{r}308 \\
51 \\
27 \\
141 \\
24 \\
551\end{array}$ & $\begin{array}{r}155 \\
111 \\
0 \\
12 \\
15 \\
293\end{array}$ \\
\hline $\begin{array}{l}\text { Chenopodium spp. (mainly C. leptophyllum) } \\
\text { Salsola kali } \\
\text { Other annuals } \\
\text { Total annuals }\end{array}$ & $\begin{array}{l}124 \\
336 \\
187 \\
647\end{array}$ & $\begin{array}{r}201 \\
48 \\
86 \\
337\end{array}$ & $\begin{array}{r}35 \\
138 \\
100 \\
273\end{array}$ & $\begin{array}{r}125 \\
11 \\
41 \\
177\end{array}$ \\
\hline $\begin{array}{l}\text { Shrubs } \\
\text { Opuntia polyacantha }\end{array}$ & $\begin{array}{l}138 \\
402 \\
\end{array}$ & $\begin{array}{r}0 \\
1084 \\
\end{array}$ & $\begin{array}{r}34 \\
409 \\
\end{array}$ & $\begin{array}{r}0 \\
1042 \\
\end{array}$ \\
\hline Total standing crop & 1716 & 1084 & 1267 & 1512 \\
\hline
\end{tabular}

todes. The material retained by the sieve was put on a Baerman funnel for 48 hours (Christie and Perry 1951). The number of nematodes in each sample (and their trophic category) was determined by counting individuals present in each of 3 1-ml subsamples of a 50-ml suspension as described by Smolik (1974). All counts were corrected for extraction efficiency, which averaged $60 \%$ for bacterial feeding nematodes, $46 \%$ for Dorylaimida, and $59 \%$ for the plant parasites. These were the 3 dominant trophic groups. The Dorylaimida consists of species which are plant parasites, predators and omnivores. But they were not assigned to trophic groups since species determination was not possible within the scope of this study.

\section{Laboratory Experiments}

To determine nematode response to different moisture levels, wet or dry, 16 senescent and 16 live blue grama plants were dug up from the ungrazed area and potted in 10 by $10-\mathrm{cm}$ plastic pots in the field on August 4, 1978. They were returned to the laboratory and placed in an environmental chamber which was set to duplicate both summer temperature and light regimes of the Central Plains Experimental Range. Half of the senescing plants and half of the live plants were watered every 2 days (wet treatment) and the remaining half were watered every 4 days (dry treatment) to field capacity. On November 4 , the nematodes were extracted and counted as described above.

\section{Analysis}

Logrithmic transformations of nematode counts were accomplished to provide normally distributed data for analysis of variance. The model for the field study was a stratified random design with 2 factors: date and plant type. There were 8 replicates for each of 4 plant types on each of 2 or 3 sampling dates. Differences between means were compared by Least Significant Range (LSR, Sokal and Rohlf 1969).

The laboratory data were also log transformed for ANOVA. The model is a completely randomized design with 2 factors: plant type and moisturc regime.

\section{Results}

\section{Field Study}

On the ungrazed plot there was both a significant date $(\alpha \leq .001)$ and plant ( $\alpha \leq .01$ ) effect on plant parasites (Fig. 1). On all sampling dates, densities were highest under live blue grama, intermediate under senescing blue grama, and lowest under fringed sagewort and dead blue grama. Densities of plant parasites were high in the spring, low in late June, and intermediate in August under live and senescing blue grama and under the fringed sagewort. Plant parasites under dead blue grama declined in mid-season but did not

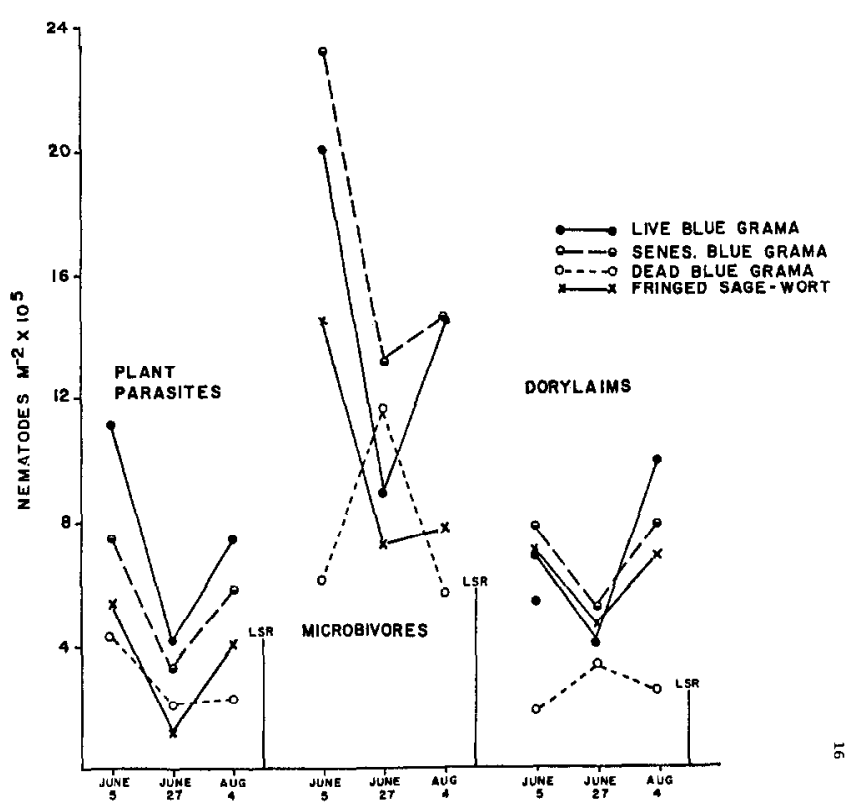

Fig. 1. Densities of plant parasites, microbivores, and Dorylaimida under live, senescing, and dead blue grama and under fringed sagewort sampled to a depth of $10 \mathrm{~cm}$ in the ungrazed area.

increase in August.

Densities of bacterial feeders (microbivores) averaged about twice those of the plant feeders and there was also a significant date $(\alpha \leq .005)$, plant $(\alpha \leq .001)$ and interaction effect $(\alpha \leq .001)$. As with the plant parasites, under the live and senescing blue grama and fringed sagewort, an early season high was followed by a significant mid-season decline $(\alpha \leq .05)$ with a subsequent increase in August (Fig. 1). The significant date-treatment interaction was caused by this mid-season high sandwiched between early and a late season low densities under dead blue grama. It is also interesting to see that on all dates there were more microbivores under senescing than under live blue grama.

The Dorylaimida (Fig. 1) (which includes omnivores, plant parasites and predators) experienced a significant treatment effect $(\alpha \leq .001)$ and a significant date-treatment interaction $(\alpha \leq .05)$. Generally, the changes reflect those of the microbial feeders except that the August densities for Dorylaimida were higher or equal to the spring densities. The Dorylaimada population under dead blue grama also appeared to have a mid-season high, but 
there was no significant difference in density among the 3 sampling dates.

The heavily grazed plot was sampled only in late June and early August. For the plant parasites (Fig. 2) there were significant date $(\alpha \leq .001)$ and treatment effects $(\alpha \leq .05)$. As in the ungrazed plots, a late June low was followed by a significant increase in August under the live and senescing plants.



Fig. 2. Densities of plant parasites, microbivores, and Dorylaimida under live, senescing, and dead blue grama and under scarlet globemallow sampled to a depth of $10 \mathrm{~cm}$ in the heavily grazed area.

A similar pattern was exhibited by some of the microbivores (Fig. 2) with a significant date $(\alpha \leq .001)$ and interaction effect $(\alpha \leq .001)$. The most notable change was an increase in densities in the live and senescing plots from June 27 to August 4 . The other treatments did not change significantly.

For the Dorylaimida the date $(\alpha \leq 001)$, treatment $(\alpha \leq 001)$ and interaction $(\alpha \leq .01)$ effects were all significant. Again, there was an increase under live and senescing plants from June to August. The scarlet globemallow population declined and the populations under dead blue grama increased but neither change was significant.

Although the ANOVA was significant in all cases, a comparison of individual mean densities at each date, usually revealed a significant difference only between the extreme values; e.g., in Figure 1 on August 4 , the plant parasites were significantly different only under live blue grama (the highest density) and dead blue grama (the lowest density). Further individual comparisons may be made by the LSR values indicated in each Figure.

\section{Laboratory}

The nematode densitics from pots of live and sencscing blue grama exposed to wet and dry treatment in the environmental chamber are shown in Figure 3. For the plant parasites and Dorylaimida there was no significant effect of either plant status or moisture. Although the live plants in the wet treatment supported twice as many nematodes on the average as the other 3 treatments, no significant difference emerged because of the high variance among pots.

For the microbivores there was a significant plant type $(\alpha \leq .05)$ and moisture effect $(\alpha \leq .05)$. The senescent plants in the dry treatment had significantly more microbivores than either of the wet

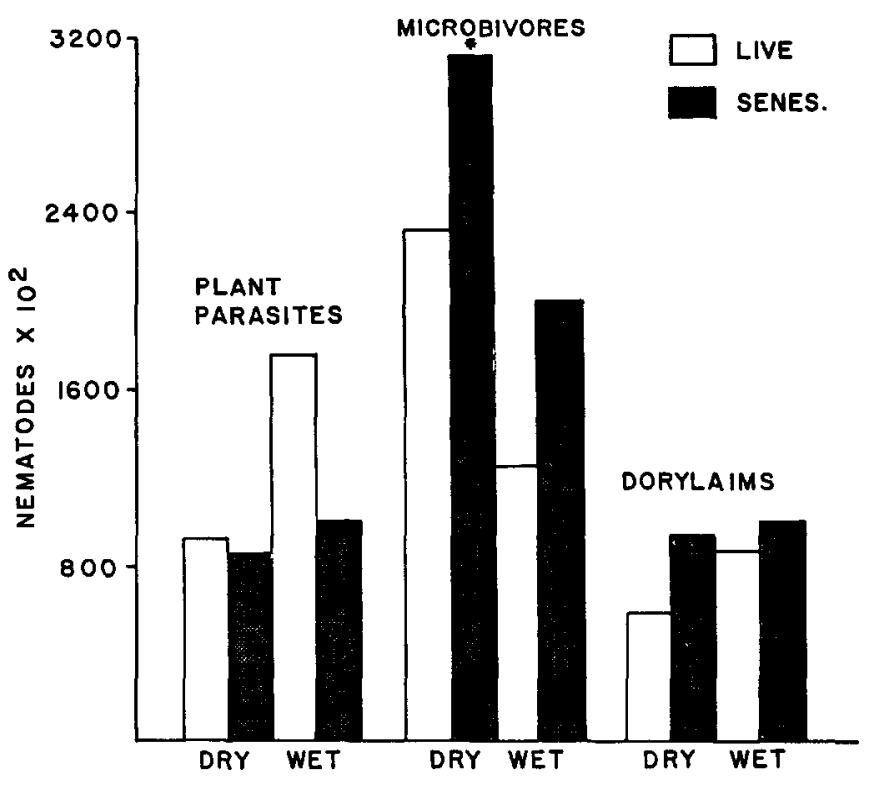

Fig. 3. Average densities of plant parasites, microbivores, and Dorylaimida extracted from pots of live and senescing blue grama subjected to either dry or wet moisture regimes in an environmental chamber. The only significant difference appeared with microbivores whose density under dry-senecing plants(") was significantly higher than the other treatments.

treatments $(\alpha \leq .05)$, and the live plants in the wet treatment supported the fewest numbers.

The mean number of microbivores per treatment was inversely, but not significantly (because of small sample size), correlated with the mean number of plant parasites per treatment $(r=.87$ in a simple linear regression); i.e., the senescent plants in the dry treatment had the largest density of microbivores and the smallest density of plant parasites. Likewise, the live plants in the wet treatment had the most plant parasites and the fewest microbivores.

\section{Discussion}

Both field and laboratory studies have shown that control of nematodes from shortgrass and mixed grass prairies could significantly increase net primary production (NPP) over the short term. Smolik (1977) found that nematicide application to mixed grass prairie vegetation increased harvestable herbage by $29-59 \%$. Stanton et al. (1981) applied nematicide to plots on the Central Plains Experimental Range and root production increased about $25 \%$. In additional laboratory experiments to measure blue grama response to both above- and below-ground grazing, Stanton (1983) indicated that populations of one species of plant parasite feeding on blue grama for 140 days reduced NPP about $13 \%$. The experimental densities were lower than field densities by at least one-half and were far less species rich (one blue grama plant in the field may host several species of plant parasites). Thus, even at normal field densities, nematodes may exert strong grazing pressure on blue grama roots.

Phytophagous nematodes probably influence plant growth; conversely, changes in root biomass may also affect nematode density. The seasonal pattern in density (early high, mid-season low, late season high) is probably a response to new roots and changes in soil moisture. Field observations, through windows placed on excavations at the Central Plains Experimental Range (Ares 1976), revealed that root growth began a short time before leaf growth in the spring. However, mid-season soil desiccation resulted in the death of $30-60 \%$ of the new roots. Late in the season with high water potential, roots again increased in length. However, it is uncertain whether the nematodes die with root die-off or enter anhydrobiosis. Anhydrobiosis is a quiescent state induced by 
lowering of soil moisture. This phenomenon has been described in a number of species (see review by Demeure and Freckman 1981) and is probably one of the reasons nematodes are so abundant in arid grasslands. They can essentially wait through periods of low soil moisture with little or no metabolic activity. When conditions become favorable, the nematodes again become active. Plant parasites were most abundant under live, healthy plants because they prefer to feed on new roots. Surprisingly, plant parasite densities under dead blue grama and fringed sagewort did not differ. Fringed sagewort generally supports fewer plant parasites than blue grama (Stanton et al. 1981). Volatile compounds such as terpenes are present in the root exudates of fringed sagewort which may deter belowground herbivores. Scarlet globemallow, also with low nematode densities, has a long, deep tap root so it probably provides fewer feeding sites than the shallow fibrous roots of blue grama. Thus, these 2 plant species do not support as large a population of nematodes as blue grama and might be at a selective advantage under stress conditions when nematode populations are high.

Microbivores were the most abundant trophic class, varying from .4 to $2.2 \times 10^{6} \mathrm{~m}^{-2}$, and populations were highest under senescing plants. Microbivores feed on bacteria and the dying roots probably provided more resources for the microbial populations. Another major carbon source for bacteria is root exudates. High exudation rate probably correlates with new root growth. Thus, with favorable moisture regimes in the spring and high root exudation, microbial populations should be high.

In the ungrazed plot the microbivore densities under dead blue grama reached a maximum in mid-season probably because the dead roots provided a large source of carbon. This is consistent with findings from our laboratory experiment in which the highest microbivore densities were from drought-stressed senescing plants.

The Dorylaimida densities were within the range of the plant parasites, and the seasonal trends in their density almost paralleled those of the microbivores. Since many of the Dorylaimida species are predators, they may use the very abundant bacterial-feeding nematodes as a major prey item.

In summary, plant parasitic densities on both the grazed and ungrazed plots under live blue grama varied from $1 \times 10^{5}$ to $1 \times$ $10^{6} / \mathrm{m}^{-2}$, well within the range reported from other areas of the Central Plains Experimental Range (R. Anderson personal com- munication, Stanton et al. 1981). Since these densities are not abnormally high, it is unlikely that nematodes were the cause of the die-off, although they certainly may have been a contributing factor. It is also possible that plant species invading the die-off patches (e.g. fringed sagewort and scarlet globemallow) are successful in part because of chemical or morphological traits that make them resistant to nematode and white grub feeding. Since nematodes may remain viable but inactive in the soil for many years, plant species which provide a root system that is palatable and accessible to nematodes may be difficult to establish even with proper climatological conditions. This idea is speculative but certainly should be investigated further.

\section{References}

Ares, J. 1976. Dynamics of the root system of blue grama. J. Range Manage. 29:208-213.

Christie, J.R., and V.G. Perry. 1951. Removing nematodes from soil. Proc. Helminth. Soc. Washingt on 18:106-108.

Demeure, Y., and D.W. Freckman. 1981. Recent advances in the study of anhydrobiotic nematodes. p. 205-226. In: B.M. Zuckerman and R.A. Rohde (Ed.). Plant parasitic nematodes Vol. IIl. Academic Press, New York.

Scott, J.A., N.R. French, and J.W. Leetham. 1979. Patterns of consumption in grasslands. p. 89-105. In: N.R. French (Ed.). Perspectives in grassland ecology. Springer-Verlag, N.Y. Heidelberg, Berlin.

Smolik, J.D. 1974. Nematode studies at the Cottonwood site. IBP Grassland Biome. Tech. Rep. No. 251. Natural Resource Ecology Laboratory, Colorado State University, Fort Collins.

Smolik, J.D. 1977. Effect of nematicide treatment on growth of range grasses in field and glasshouse studies. p. 257-260. In: J.K. Marshall (Ed.). The belowground ecosystem. Range Science Dep. Sci. Series No. 26.

Sokal, R.R., and F.J. Rohlf. 1969. Biometry. W.H. Freeman and Co. San Francisco.

Stanton, N.L., M. Allen and M. Campion. 1981. The effect of the pesticide carbofuran on soil organisms and root and shoot production in shortgrass prairie. J. App. Ecol. 18:417-431.

Stanton, N.L. 1983. The effect of clipping and phytophagous nematodes on net primary production of blue grama, Bouteloua gracilis. Oikos 40:249-257.

Wiener, L.F. and J.L. Capinera. 1980. Preliminary study of the biology of the white grub Phyllophaga fimbripes (leConte) (Coleoptera: Scarabaeidae). J. Kansas Entom. Soc. 53:701-710.

\section{Membership in the Society for Range Management. . .}

is open to those engaged in or interested in the study. management, or use of range ecosystems and the intelligent use of all range resources

includes research scientists, ranchers, governmental agency administrators and technical personnel. teochers. students, and people from the business community

- provides members with two publications-one oriented to research (Journal of Range Management) and the other oriented to practical resource management (Rangelands) offers opportunities for face-to-face exchange of ideas at local, national, and intemational meetings of the Society.

Dues vary according to type of membership and geographical section. For application forms and additional information, contact the:

Society for Range Management

2760 West Fitth Avenue

Denver. Colorado 80204

(303) 571-0174 